\title{
ANALISA KEPUASAN PENGGUNA APLIKASI E- PUNTEN KOTA BANDUNG MENGGUNAKAN MODEL EVALUASI TERINTEGRASI
}

\author{
Rizal Rachman', Nanang Hunaifi' ${ }^{2}$ R. Dewi Sulatriningsih ${ }^{3}$ \\ 1STMIK Nusa Mandiri \\ e-mail: rizalkhaizuran@gmail.com \\ ${ }^{2}$ Universitas Bina Sarana Informatika \\ e-mail: masnaing@gmail.com \\ ${ }^{3}$ Universitas Adhirajasa Reswara Sanjaya \\ e-mail: r.dewi.sulastriningsih@gmail.com
}

\begin{abstract}
Abstak
Pemerintah Kota Bandung melalui Dinas Kependudukan dan Pencatatan Sipil Kota Bandung meluncurkan inovasi bernama e-PunTEN atau kepanjangan dari pendaftaran penduduk tidak permanen. Aplikasi e-PunTEN adalah sarana untuk menangani sertifikat tinggal sementara yang dikeluarkan oleh Disdukcapil Kota Bandung. Ada dua versi aplikasi e-PunTEN, versi web dan seluler. Alasan pemerintah kota Bandung menerbitkan aplikasi aplikasi e-PunTEN sebagai solusi untuk meningkatkan kualitas layanan publik. Terwujudnya pelayanan administrasi yang berkualitas merupakan salah satu ciri kepemerintahan yang baik sebagai tujuan dari pendayagunaan aparatur Negara. Dalam penelitian ini penulis menggunakan model penelitian evaluasi terintegrasi dengan lima variabel, yaitu faktor manusia, faktor organisasi, faktor teknologi, niat perilaku dan kepuasan pengguna. Dalam mengumpulkan data penulis menggunakan kuesioner yang dibagikan kepada 100 responden. Dari hasil pengolahan data diperoleh hasil yang signifikan diketahui bahwa faktor manusia 5,7\%, faktor organisasi $2,9 \%$, faktor teknologi memiliki nilai signifikan $17,5 \%$, dan niat pengguna $52,1 \%$. Dapat disimpulkan bahwa niat pengguna berpengaruh sangat positif terhadap kepuasan pengguna.
\end{abstract}

Kata Kunci: e-PunTEN, evaluasi terintegrasi, kepuasan

\begin{abstract}
Bandung City Government through the Department of Population and Civil Registration of Bandung City launched an innovation called e-PUnTEN or an extension of non-permanent population registration. The e-PUnTEN application is a means to handle temporary residence certificates issued by Disdukcapil Kota Bandung. There are two versions of the e-PunTEN application, web and mobile versions. The reason the city government of Bandung published ePUnTEN application as a solution to improve the quality of public services. The realization of quality administrative services is one of the characteristics of good governance as the goal of the utilization of the State apparatus. In this study the authors used an integrated evaluation research model with five variables, namely human factors, organizational factors, technological factors, behavioral intentions and user satisfaction. In collecting data the authors used a questionnaire that was distributed to 100 respondents. From the results of data processing it is obtained that significant results are known that human factors are 5.7\%, organizational factors are $2.9 \%$, technological factors have a significant value of $17.5 \%$, and user intentions are $52.1 \%$. It can be concluded that the user's intention has a very positive effect on user satisfaction.
\end{abstract}

Keywords: e-PUnTEN application, integrated evaluation, satisfactioni 


\section{Pendahuluan}

Pemerintah Kota Bandung melalui Dinas Kependudukan dan Pencatatan Sipil Kota Bandung meluncurkan inovasi bernama e-PunTEN atau kepanjangan dari pendaftaran penduduk tidak permanen. Aplikasi e-PunTEN yang diresmikan langsung oleh Wali Kota Bandung Ridwan Kamil, merupakan sarana dalam pengurusan surat keterangan tinggal sementara yang diterbitkan oleh Disdukcapil Kota Bandung, dan diberikan kepada Warga Negara Indonesia yang tinggal sementara di suatu kota atau kabupaten (Istiqomah,2017).

Menurut Mantra dalam Agusta (2013) mengatakan bahwa "Migrasi adalah perpindahan penduduk dari satu wilayah ke wilayah lain dengan maksud untuk menetap di daerah tujuan. Sedangkan mobilitas sirkuler ialah gerakan penduduk dari satu tempat ke tempat lain dengan tidak ada niat untuk menetap di daerah tujuan. Secara operasional, migrasi dapat diukur berdasarkan konsep ruang dan waktu. Seseorang dapat disebut sebagai seorang migran, apabila orang tersebut melintasi batas wilayah administrasi dan lamanya bertempat tinggal di daerah tujuan minimal enam bulan" (Agusta, 2013).

Peraturan Pemerintah No.57 Tahun 2009 Pasal 16H menjelaskan bahwa Dalam penyelenggaraan Pengarahan Mobilitas Penduduk, Pemerintah melakukan : (a) Pengumpulan dan pengembangan sistem database serta analisis data mobilitas atau persebaran penduduk sebagai dasar dalam penyusunan kebijakan dan perencanaan pembangunan berwawasan kependudukan. (b) Pengembangan sistem informasi kesempatan kerja, peluang usaha dan pasar kerja serta kondisi daerah tujuan. (c) Pengkajian, penelitian dan pengembangan terhadap efektivitas kebijakan pengarahan mobilitas penduduk. (d) Sosialisasi, advokasi dan komunikasi mengenai kebijakan pengarahan mobilitas penduduk kepada seluruh instansi terkait. (e) Pembinaan dan fasilitasi kebijakan pengarahan mobilitas penduduk kepada seluruh instansi terkait. (f) Pemantauan dan evaluasi serta pengawasan terhadap pelaksanaan kebijakan pengarahan mobilitas penduduk. dan (g) Pengendalian dampak mobilitas penduduk terhadap pembangunan dan lingkungan.

Dinas kependudukan dan catatan sipil atau Dispendukcapil adalah dinas yang menangani tentang pencatatan kependudukan, diantaranya mengenai hal mulai dari kelahiran, kematian, izin tinggal warga pendatang, pembuatan kartu tanda penduduk, pembuatan kartu keluarga dan akta kelahiran. Pelayanan publik menurut Undang-Undang Republik Indonesia Nomor 25 Tahun 2009 tentang Pelayanan Publik adalah kegiatan atau rangkaian kegiatan dalam rangka pemenuhan kebutuhan pelayanan sesuai peraturan perundangundangan bagi setiap warga negara dan penduduk atas barang, jasa, atau pelayanan administratif yang disediakan oleh pemerintah (http://peraturan.go.id).

Untuk memantau dan mengawasi pelaksanaan kebijakan pengarahan serta mengendalikan dampak mobilitas penduduk, pendatang dari luar daerah dalam jangka waktu tertentu diwajibkan melaporkan diri untuk kepentingan administrasi kependudukan. Menurut Hidayat dalam Martini \& Sudibya (2013) Adapun dampak positif yang disebabkan oleh mobilitas penduduk adalah meningkatnya status sosial ekonomi keluarga tersebut dalam jangka panjang. Tidak hanya sekedar mampu meningkatkan kesejahteraan keluarga, namun lebih dari itu, akan mampu mengurangi kesenjangan antara kemakmuran di kota dan desa. Sebaliknya dampak negatif yang ditimbulkan adalah terbatasnya kesempatan kerja yang ada, sehingga menimbulkan tingginya angka pengangguran diperkotaan. Berkembangnya sektor informal di perkotaan menyebabkan mereka berupaya hidup hemat dan memilih tinggal di pemukiman kumuh. Pemukimankumuh di daerah perkotaan memicu terjadinya pencemaran lingkungan, yang berdampak pada rendahnya tingkat kesehatan di kota (Martini \& Sudibya, 2013).

Terwujudnya pelayanan administrasi yang berkualitas merupakan salah satu ciri kepemerintahan yang baik sebagai tujuan dari pendayagunaan aparatur negara. Untuk itu, aparatur negara diharapkan semakin efisien dan efektif melaksanakan tugas dan tanggung jawabnya dalam menyelenggarakan pemerintahan, pembangunan, dan pengayoman kepada masyarakat untuk mewujudkan terselenggaranya pemerintahan yang baik, serta memberikan pelayanan prima kepada masyarakat (Yunita, 2017).

Mengingat begitu besarnya dampak positif maupun negatif yang disebabkan oleh 
mobilitas penduduk bagi suatu daerah atau kota, maka penulis tertarik untuk melakukan penelitian terhadap aplikasi e-PunTEN. Dalam penelitian ini penulis menggunakan model evaluasi terintegrasi dari model penerimaan UTAUT (Unified Theory Of Acceptance And Use Of Technology), model kesuksesan sistem informasi Delone dan McLeaon dan model kesesuaian manusiaorganisasi-teknologi HOT FIT (Human, Organization, Technology Fit ) yang nantinya dapat menggambarkan kepuasan pengguna dari aplikasi E-Punteun yang dikeluarkan Pemkot Bandung.

\section{Metode Penelitian}

A. Unified Theory of Acceptance and Usage of Technology (UTAUT)

Empat bagian dari metode UTAUT yaitu :

1. Harapan kinerja (performance expectancy)

2. Harapan usaha (effort expectancy)

3. Pengaruh social (social influence)

4. Kondisi-kondisi fasilitas (facilitating conditions)

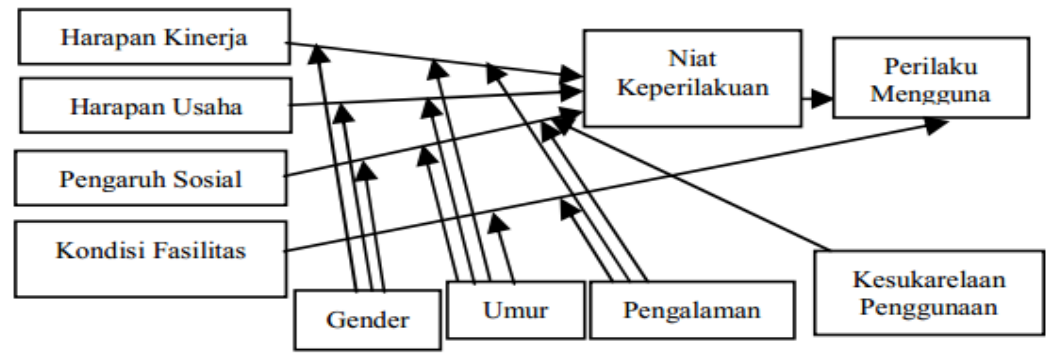

Sumber : (Venkatesh, 2003)

Gambar 1

Model Unified Theory of Acceptance and Usage of Technology (UTAUT)

B. Model Kesuksesan Delone dan McLean Tiga bagian dari model Delone dan McLean adalah :

1. Kualitas informasi, kualitas sistem, dan kualitas layanan.
2. Keguanaan dan kepuasan pengguna.

3. Individual impact dan organizational impact (net benefit).

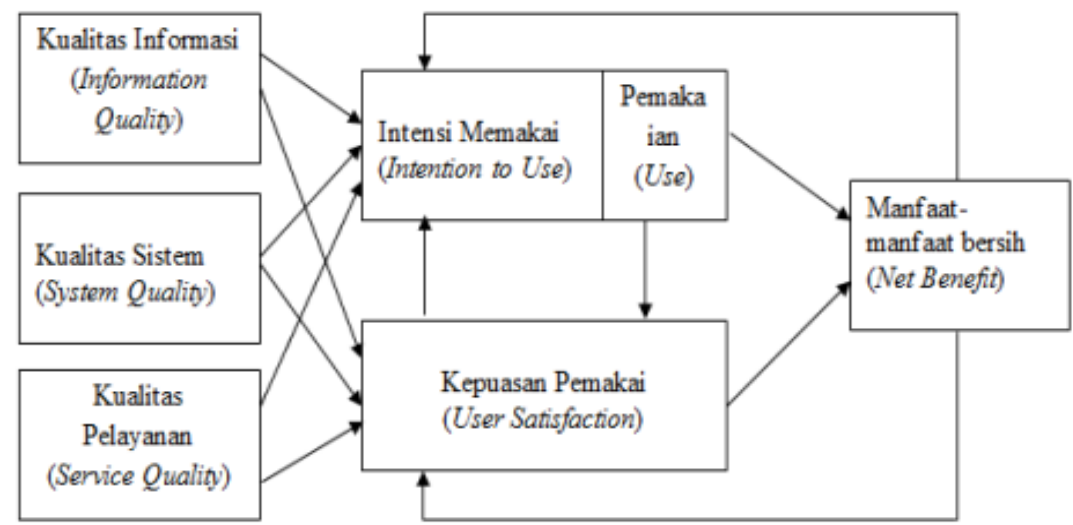

Sumber : (Jogiyanto, 2007)

Gambar 2.

Model Kesuksesan Delone dan McLean

\section{Human, Organization, Technology Fit (Hot Fit)}

Ada tiga komponen yang ada dalam Hot Fit yaitu :
1. Manusia (Human).

2. Organisasi (Organization)

3. Teknologi (Technology). 


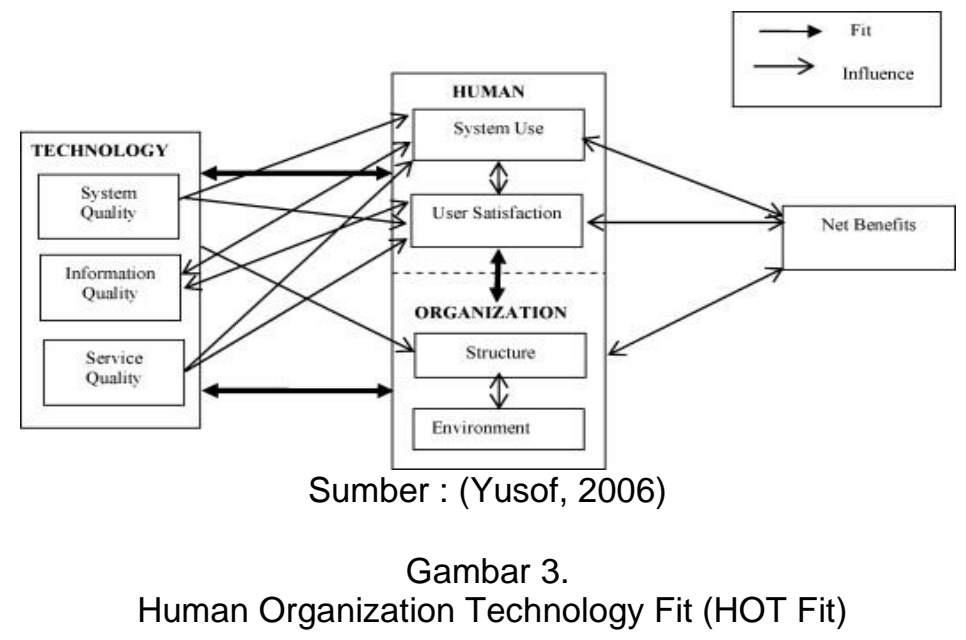

\section{Model Evaluasi Terintegrasi}

Model evaluasi terintegrasi ini dapat mengetahui dampak dari penggunaan sistem yang membagi faktor penentu menjadi tiga klasifikasi besar yakni manusia, organisasi, dan teknologi. Pengguna atau manusia perlu dievaluasi karena berhubungan langsung dengan sistem, organisasi perlu dievaluasi karena pengenalan teknologi informasi baru dapat mengubah layanan, operasi, dan struktur organisasi, dan teknologi perlu dievaluasi karena menjadi bagian dari sistem (Mohamadali, 2010).

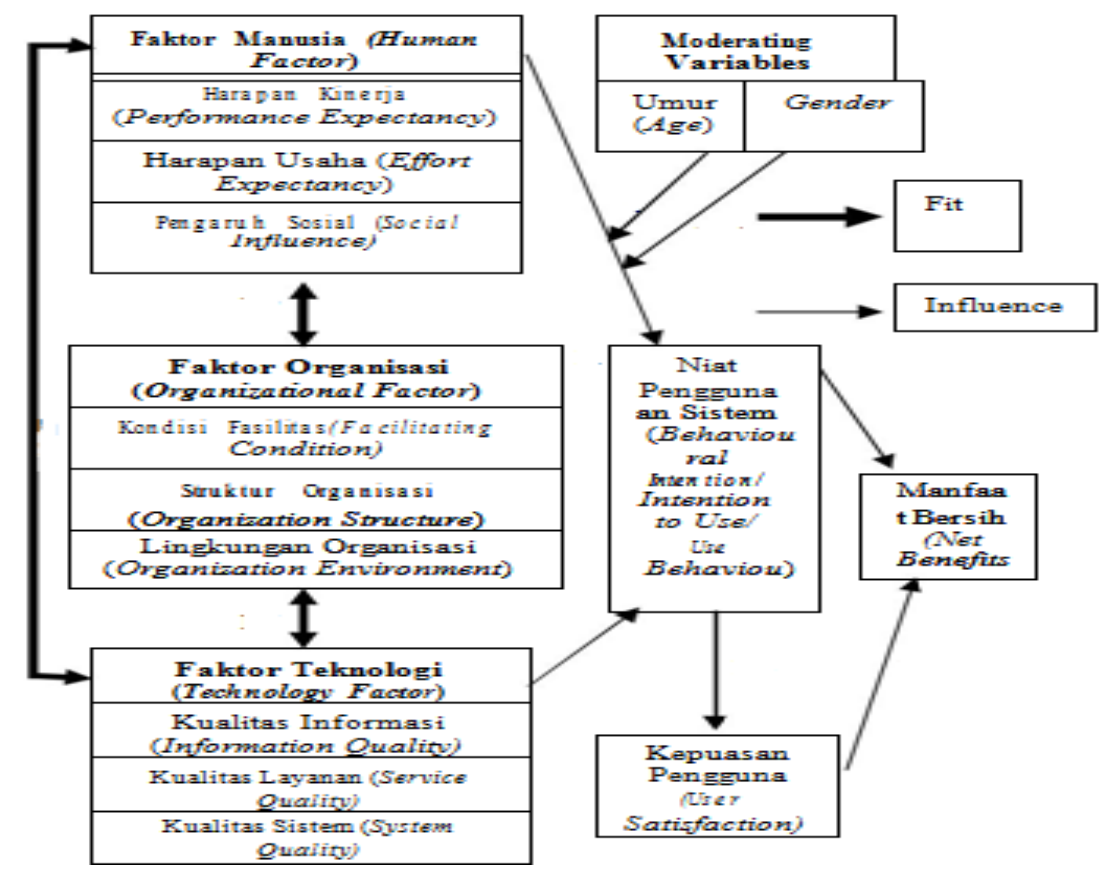

Sumber : (Mohamadali, 2010)

Gambar 4. Model Evaluasi Terintegrasi

\section{Hasil dan Pembahasan}

Pengujian hipotesis adalah suatu prosedur yang akan menghasilkan suatu keputusan, yaitu keputusan dalam menerima atau menolak hipotesis ini. keputusan bisa benar atau salah (Misbahuddin, 2013). Uji hipotesis yang digunakan dalam penelitian ini adalah Uji t dan Uji F.
A. Uji t

Uji t dilakukan dengan mengetahui $t$ tabel menggunakan rumus $\mathrm{t}$ tabel $=\mathrm{t}(\alpha / 2 ; n-k$ 1). Maka perhitungan nya adalah $t(0,025$; 
96), dapat diketahui nilai t tabel adalah 1,98498 .

Hasil Uji t pada hipotesis 1, hipotesis 2, dan hipotesis 3 penelitian ini dapat dilihat pada tabel 1:

Tabel 1. Hasil Uji t $X_{1}, X_{2}$ dan $X_{3}$ Terhadap Niat Pengguna

\begin{tabular}{|c|c|c|c|c|c|c|}
\hline \multicolumn{7}{|c|}{ Coefficients $^{a}$} \\
\hline \multirow{2}{*}{\multicolumn{2}{|c|}{ Model }} & \multicolumn{2}{|c|}{$\begin{array}{l}\text { Unstandardized } \\
\text { Coefficients }\end{array}$} & $\begin{array}{l}\text { Standardized } \\
\text { Coefficients }\end{array}$ & & \\
\hline & & $\mathrm{B}$ & Std. Error & Beta & $t$ & Sig. \\
\hline 1 & \begin{tabular}{|l|} 
(Const \\
ant) \\
\end{tabular} & ,229 & 1,055 & & 217 & ,829 \\
\hline & $\begin{array}{l}\text { Faktor } \\
\text { Manusi } \\
\text { a }\end{array}$ & 198 & ,077 & 239 & $\begin{array}{r}2,56 \\
9\end{array}$ & ,012 \\
\hline & $\begin{array}{l}\text { Faktor } \\
\text { Organi } \\
\text { sasi }\end{array}$ & 184 & 104 & 172 & $\begin{array}{r}1,76 \\
4\end{array}$ & ,081 \\
\hline & $\begin{array}{l}\text { Faktor } \\
\text { teknolo } \\
\text { gi }\end{array}$ & 250 &, 060 & ,415 & $\begin{array}{r}4,17 \\
1\end{array}$ & ,000 \\
\hline
\end{tabular}

Berdasarkan tabel 1, dapat diketahui hasil pengujian hipotesis sebagai berikut:

\section{Hipotesis 1}

$\mathrm{H}_{0}$ : Faktor manusia (Human factor) tidak berpengaruh signifikan terhadap niat pengguna (Behavioral intention).

$\mathrm{Ha}$ : Faktor manusia (Human factor) berpengaruh signifikan terhadap niat pengguna (Behavioral intention).

Dapat dilihat dari nilai $t$ hitung pada faktor manusia adalah 2,569 dan nilai t tabel adalah 1,98498, serta signifikan sebesar 0,12 . Karena nilai t hitung $>t$ tabel, dan nilai signifikan $>0$, 05, maka $\mathrm{Ho}$ ditolak dan $\mathrm{Ha}$ diterima sehingga dikatakan terdapat pengaruh signifikan antara Faktor manusia (Human factor) terhadap niat pengguna (Behavioral intention).

Hipotesis 2

$\mathrm{H}_{0}$ : Faktor organisasi (Organization factor) tidak berpengaruh signifikan terhadap niat pengguna (Behavioral intention).

$\mathrm{Ha}$ : Faktor organisasi (Organization factor) berpengaruh signifikan terhadap niat pengguna (Behavioral intention).

Dapat dilihat dari nilai $t$ hitung pada faktor organisasi adalah 1,764 dan nilai $t$ tabel adalah 1,98498, serta signifikan sebesar 0,81 . Karena nilai t hitung $<\mathrm{t}$ tabel, dan nilai signifikan $>0,05$, maka Ho diterima sehingga dikatakan faktor organisasi (Organization factor) tidak berpengaruh terhadap niat pengguna (Behavioral intention).
Hipotesis 3

Ho: Apakah faktor teknologi (Technology Factor) tidak berpengaruh positif terhadap niat penggunaan sistem (Behavioral intention).

Ha : Apakah faktor organisasi (Technology Factor) berpengaruh positif terhadap niat penggunaan sistem (Behavioral intention).

Dapat dilihat dari nilai t hitung pada faktor teknologi adalah 4,171 dan nilai t tabel adalah 1,98498, serta signifikan sebesar 0,00 . Karena nilai t hitung $>\mathrm{t}$ tabel, dan nilai signifikan < 0, 05, maka Ho ditolak dan $\mathrm{Ha}$ diterima sehingga dikatakan terdapat pengaruh signifikan antara faktor teknologi (Technology Factor) terhadap niat penggunaan sistem (Behavioral intention).

Tabel 2.

Hasil Uji t Y Niat Pengguna Terhadap Kepuasan pengguna

\begin{tabular}{|c|c|c|c|c|c|c|}
\hline \multirow{3}{*}{\multicolumn{2}{|c|}{ Model }} & \multicolumn{4}{|c|}{ Coefficients $^{\mathrm{a}}$} & \multirow[b]{3}{*}{ Sig. } \\
\hline & & \multicolumn{2}{|c|}{$\begin{array}{c}\text { Unstandardized } \\
\text { Coefficients }\end{array}$} & \multirow{2}{*}{$\begin{array}{c}\begin{array}{c}\text { Standardi } \\
\text { zed }\end{array} \\
\begin{array}{c}\text { Coefficient } \\
\mathrm{s}\end{array} \\
\text { Beta }\end{array}$} & \multirow[b]{2}{*}{$\mathrm{T}$} & \\
\hline & & B & $\begin{array}{l}\text { Std. } \\
\text { Error }\end{array}$ & & & \\
\hline 1 & $\begin{array}{c}\text { (Constan } \\
\mathrm{t})\end{array}$ & 4,967 & ,997 & & $\begin{array}{c}4,98 \\
1\end{array}$ & $\begin{array}{c}, 00 \\
0\end{array}$ \\
\hline & $\begin{array}{c}\text { Niat } \\
\text { Penggun } \\
a\end{array}$ & ,946 & ,091 & ,722 & $\begin{array}{c}10,3 \\
40\end{array}$ & $\begin{array}{c}, 00 \\
0\end{array}$ \\
\hline
\end{tabular}

Hipotesis 4

HO : Niat penggunaan (Behavioral intention) tidak berpengaruh signifikan terhadap kepuasan pengguna (User Satisfiction).

$\mathrm{Ha}$ : Niat penggunaan (Behavioral intention) berpengaruh signifikan terhadap kepuasan pengguna (User Satisfiction).

Dapat dilihat dari nilai $t$ hitung pada faktor organisasi adalah 10,34 dan nilai $t$ tabel adalah 1,98498, serta signifikan sebesar 0,00. Karena nilai t hitung $>\mathrm{t}$ tabel, dan nilai signifikan $<0,05$, maka $\mathrm{H}_{\circ}$ ditolak dan Ha diterima sehingga dikatakan terdapat pengaruh signifikan antara niat penggunaan sistem (Behavioral intention) terhadap kepuasan pengguna (User Satisfiction). 


\section{B. Uji F}

Uji $F$ dilakukan dengan mengetahui $F$ tabel menggunakan rumus $\mathrm{F}$ tabel $=\mathrm{F}(\mathrm{k} ; \mathrm{n}-\mathrm{k})$. Maka perhitungan nya adalah $F(3 ; 96)$, dapat diketahui nilai $\mathrm{F}$ tabel adalah 2,70.

Tabel 3.

Hasil SPSS Uji F

\begin{tabular}{|c|c|c|c|c|c|c|}
\hline \multicolumn{7}{|c|}{ ANOVA $^{a}$} \\
\hline \multicolumn{2}{|c|}{ Model } & $\begin{array}{l}\text { Sum of } \\
\text { Squares }\end{array}$ & Df & $\begin{array}{c}\text { Mean } \\
\text { Square }\end{array}$ & $\mathrm{F}$ & Sig. \\
\hline 1 & $\begin{array}{l}\text { Regres } \\
\text { sion }\end{array}$ & 117,397 & 3 & 39,132 & $\begin{array}{r}33 \\
, 9 \\
66\end{array}$ &, 000 \\
\hline & $\begin{array}{l}\text { Residu } \\
\text { al }\end{array}$ & 110,603 & 96 & 1,152 & & \\
\hline & Total & 228,000 & 99 & & & \\
\hline \multicolumn{7}{|c|}{ a. Dependent Variable: Niat Pengguna } \\
\hline \multicolumn{7}{|c|}{$\begin{array}{l}\text { b. Predictors: (Constant), Faktor teknologi, Faktor } \\
\text { Manusia, Faktor Organisasi }\end{array}$} \\
\hline
\end{tabular}

Berdasarkan Tabel IV.73. diatas, dapat diketahui hasil pengujian hipotesis 4 sebagai berikut:

Ho: Faktor Manusia (Human Factor), Faktor Organisasi (Organization Factor) dan Faktor Teknologi (Technology Factor), secara bersamasama tidak berpengaruh terhadap Niat Penggunaan (Behavioral intention).

$\mathrm{H}_{\mathrm{a}}$ : Faktor Manusia (Human Factor), Faktor Organisasi (Organization Factor) dan Faktor Teknologi (Technology Factor), secara bersamasama berpengaruh terhadap Niat Pengguna (Behavioral intention).

Dari tabel diatas diperoleh nilai $F$ hitung sebesar 33,966 . Langkah selanjutnya mencari nilai $F$ tabel dan membandingkan dengan nilai $F$ hitung 33,966 . Rumus mencari $\mathrm{F}$ tabel adalah $(\mathrm{k} ; \mathrm{n}-\mathrm{k})$ dengan keterangan sebagai berikut :

- $\mathrm{k}=$ jumlah variabel independen (bebas)

- $\mathrm{n}=$ jumlah responden atau sampel penelitian

Data diatas menunjukkan bahwa $\mathrm{k}=3$ $\left(\mathrm{X}_{1}\right.$ Human factor, $\mathrm{X}_{2}$ Organization factor, dan $X_{3}$ Tecnologi factor) dan $n=100$. Selanjutnya masukan kedalam rumus, maka menghasilkan angka $(3 ; 100-3)=(3 ; 97)$, angka ini yang digunakan sebagai acuan untuk mencari $F$ tabel pada distribusi $F$ tabel statistic. Maka diketahui bahwa nilai $\mathrm{F}$ tabel sebesar 2,70. Karena nilai $F$ hitung 35,162 lebih besar dari $F$ tabel 2,70 maka ditarik kesimpulan bahwa variabel bebas $\mathrm{X}_{1}, \mathrm{X}_{2}$, dan
$X_{3}$ secara simultan berpengaruh terhadap variabel terikat.

\section{Analisis Jalur (Path Analysis)}

Analisis jalur (Path Analysis) dilakukan untuk mengetahui hubungan struktural antara variabel eksogen (Bebas) terhadap variabel endogen (Terikat), dan untuk mengetahui besarnya pengaruh langsung, dan pengaruh total dari variabel endogen (Terikat) terhadap variabel eksogen (Bebas). Persamaan bentuk diagram koefisien jalur sebagai berikut:

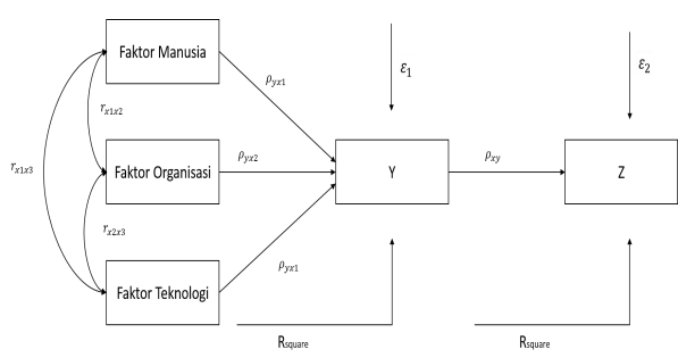

Gambar 5.

Hubungan Struktur Variabel $X_{1}, X_{2}$, dan $X_{3}$ terhadap Variabel $Y$ dan $Z$

Untuk mengetahui nilai korelasi antar variabel bebas, maka dilakukan perhitungan korelasi menggunakan SPSS 22 dibawah ini.

Tabel 4.

Koefisien Korelasi Variabel Bebas

\begin{tabular}{|c|c|c|c|c|c|c|}
\hline \multicolumn{7}{|c|}{ Correlations } \\
\hline & & $\begin{array}{c}\text { Fakto } \\
r \\
\text { Manu } \\
\text { sia }\end{array}$ & $\begin{array}{c}\text { Faktor } \\
\text { Organis } \\
\text { asi }\end{array}$ & $\begin{array}{c}\text { Fakto } \\
r \\
\text { teknol } \\
\text { ogi }\end{array}$ & $\begin{array}{c}\text { Niat } \\
\text { Pen } \\
\text { ggu } \\
\text { na }\end{array}$ & $\begin{array}{c}\text { Kepu } \\
\text { asan } \\
\text { Peng } \\
\text { una }\end{array}$ \\
\hline \multirow[t]{3}{*}{$\begin{array}{l}\text { Fak } \\
\text { tor } \\
\text { Ma } \\
\text { nusi } \\
\text { a }\end{array}$} & $\begin{array}{l}\text { Pea } \\
\text { rso } \\
n \\
\text { Cor } \\
\text { rela } \\
\text { tion }\end{array}$ & 1 &, $572^{* *}$ &, $596^{\star *}$ & $\frac{, 58}{4^{* *}}$ &, $587^{* *}$ \\
\hline & $\begin{array}{l}\text { Sig. } \\
(2- \\
\text { taile } \\
\text { d) } \\
\end{array}$ & &, 000 &, 000 & $\begin{array}{r}, 00 \\
0\end{array}$ &, 000 \\
\hline & $\mathrm{N}$ & 100 & 100 & 100 & 100 & 100 \\
\hline \multirow[t]{3}{*}{$\begin{array}{l}\text { Fak } \\
\text { tor } \\
\text { Org } \\
\text { anis } \\
\text { asi }\end{array}$} & $\begin{array}{l}\text { Pea } \\
\text { rso } \\
n \\
\text { Cor } \\
\text { rela } \\
\text { tion }\end{array}$ &, $572^{* \star}$ & 1 &, $641^{* *}$ & $\begin{array}{l}, 57 \\
4^{* *}\end{array}$ &, $607^{* *}$ \\
\hline & $\begin{array}{l}\text { Sig. } \\
(2- \\
\text { taile } \\
\text { d) } \\
\end{array}$ & ,000 & & ,000 & $\begin{array}{r}, 00 \\
0\end{array}$ &, 000 \\
\hline & $\mathrm{N}$ & 100 & 100 & 100 & 100 & 100 \\
\hline
\end{tabular}




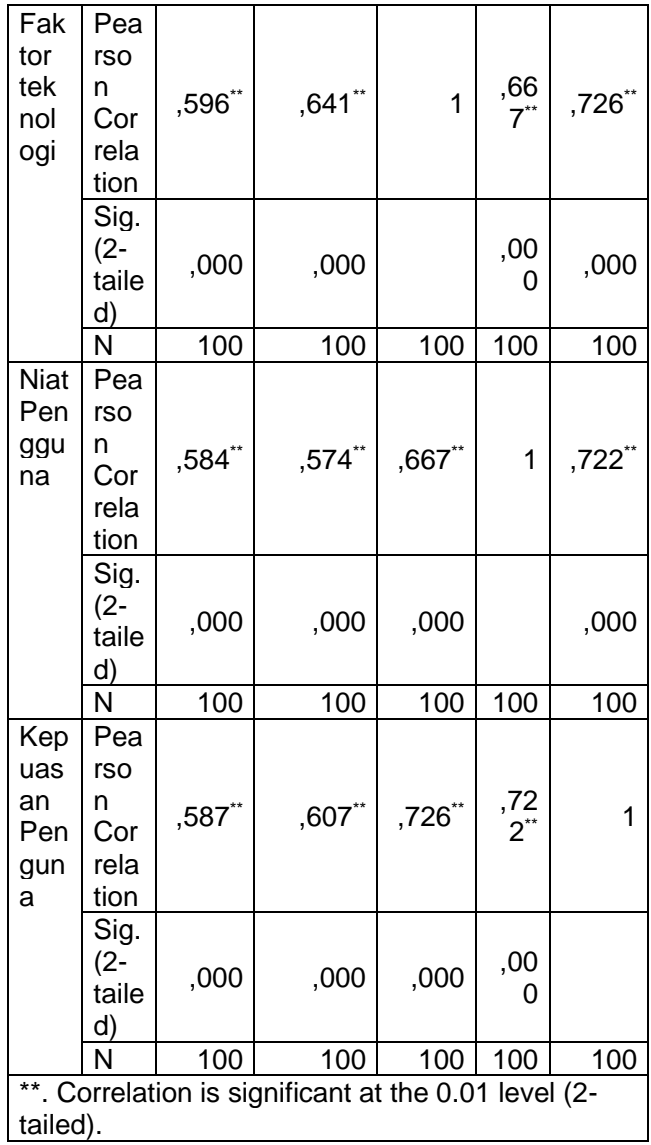

Nilai $R_{\text {square }}$ didapat dari hasil $U_{j i} R_{\text {square }}$ , yaitu sebesar 0,854 . Nilai $\varepsilon$ merupakan nilai pengaruh dari variabel lain dari luar model yang didapat dari $U_{j i} R_{\text {square }}$, yaitu sebesar 0,146 . Nilai $\rho_{Y X_{1}}, \rho_{Y X_{2}}, \rho_{Y X_{3}}$ merupakan nilai pengaruh masing-masing variabel bebas terhadap variabel terikat yang didapat dari nilai Beta pada hasil Uji t, yaitu $\rho_{Y X_{1}}=0,239$, $\rho_{Y X_{2}}=0,172, \rho_{Y X_{3}}=0,415, \rho_{x y}=0,722$. Nilai $r_{\times 1 \times 2}, r_{x 2 \times 3}, r_{x 1 \times 3}$ merupakan nilai koefisien korelasi masing-masing variabel bebas yaitu sebesar $r_{\times 1 \times 2}=0,572, r_{\times 2 \times 3}=0,641, r_{\times 1 \times 3}=$ 0,596 , yang didapat dari tabel koefisien korelasi.

Maka didapat diagram jalur hubungan kausal empiris Faktor Manusia $\left(X_{1}\right)$, dan Faktor Teknologi $\left(X_{2}\right)$, Faktor Organisasi $\left(\mathrm{X}_{3}\right)$ terhadap Niat Pengguna $(\mathrm{Y})$ dan Niat Pengguna terhadap Kepuasan (Z) sebagai berikut:

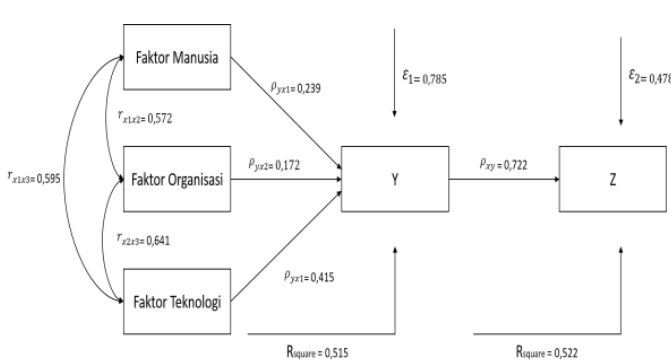

Gambar 6

Hasil Diagram Hubungan Struktur Variabel $X_{1}, X_{2}$, dan $X_{3}$ terhadap Variabel $Y$ dan $Z$ Persamaan struktural untuk diagram jalur sebagai berikut:

$Y=\rho_{Y X_{1}} X_{1}+\rho_{Y X_{2}} X_{2}+\rho_{Y X 3} X_{3}+\varepsilon$

$Y=0,239 X_{1}+0,172 X_{2}+0,415 X_{3}+0,515$

$\varepsilon$

$Z=\rho_{x y}+\varepsilon$

$\mathrm{Z}=0,722+0,522 \varepsilon$

Maka hasil analisis jalurnya adalah:

a. Kontribusi Faktor Manusia $\left(X_{1}\right)$ yang secara langsung mempengaruhi Niat Pengguna $(\mathrm{Y})$ sebesar $0,239^{2}=0,057$ atau $5,7 \%$

b. Kontribusi faktor Organisasi $\left(\mathrm{X}_{2}\right)$ yang secara langsung mempengaruhi Niat Pengguna $(\mathrm{Y})$ sebesar $0,172^{2}=0,029$ atau 2,9\%

c. Kontribusi Faktor Teknologi $\left(X_{3}\right)$ yang secara langsung mempengaruhi Niat Pengguna $(\mathrm{Y})$ sebesar $0,415^{2}=0,173$ atau $17.3 \%$.

d. Kontribusi Faktor Manusia $\left(X_{1}\right)$, Faktor Organisasi $\left(\mathrm{X}_{2}\right)$, dan Faktor Teknologi $\left(X_{3}\right)$ secara simultan yang langsung mempengaruhi Niat Pengguna (Y) sebesar $R^{2}$ square $=0,515=51,5 \%$. Sisanya dipengaruhi oleh faktor lain sebesar $0,485=48,5 \%$.

e. Kontribusi Niat Pengguna $(Y)$ yang secara langsung mempengaruhi Kepuasan Pengguna (Z) sebesar $0,722^{2}=0,521$ atau $52.1 \%$

f. Kontribusi Niat Pengguna (Y) secara simultan yang langsung mempengaruhi Kepuasan Pengguna (Z) sebesar $R^{2}$ square $=0,522=52,2 \%$. Sisanya dipengaruhi oleh faktor lain sebesar $0,478=47,8 \%$.

Hasil analisis jalur dapat disimpulkan pada tabel dibawah ini: 
Tabel 5.

Total Pengaruh Langsung Dan Tidak Langsung

\begin{tabular}{|c|c|c|c|c|c|c|c|}
\hline \multirow[t]{2}{*}{$\begin{array}{c}\text { Varia } \\
\text { bel }\end{array}$} & \multirow[t]{2}{*}{$\begin{array}{l}\text { Koefi } \\
\text { sien } \\
\text { Beta }\end{array}$} & \multirow{2}{*}{$\begin{array}{l}\text { Peng } \\
\text { aruh } \\
\text { Lags } \\
\text { ung }\end{array}$} & \multicolumn{3}{|c|}{$\begin{array}{l}\text { Pengaruh Tidak } \\
\text { Langsung } \\
\text { Terhadap Y } \\
\text { Melalui }\end{array}$} & \multirow{2}{*}{$\begin{array}{c}\text { Total } \\
\text { Peng } \\
\text { aruh } \\
\text { Tida } \\
\mathrm{k} \\
\text { Lang } \\
\text { sung }\end{array}$} & \multirow[t]{2}{*}{$\begin{array}{l}\text { Total } \\
\text { Peng } \\
\text { aruh }\end{array}$} \\
\hline & & & $\mathrm{X} 1$ & $\mathrm{x} 2$ & $\mathrm{X} 3$ & & \\
\hline $\mathrm{X} 1$ & 0,239 & 0,057 & & $\begin{array}{l}0,0 \\
23\end{array}$ & $\begin{array}{l}0,0 \\
59\end{array}$ & $\begin{array}{c}0,08 \\
2\end{array}$ & $\begin{array}{c}0,13 \\
9\end{array}$ \\
\hline $\mathrm{X} 2$ & 0,172 & 0,029 & $\begin{array}{l}0,0 \\
23\end{array}$ & & $\begin{array}{l}0,0 \\
45\end{array}$ & $\begin{array}{c}0,06 \\
8\end{array}$ & $\begin{array}{c}0,09 \\
7\end{array}$ \\
\hline $\mathrm{X} 3$ & 0,415 & 0,173 & $\begin{array}{l}0,0 \\
59\end{array}$ & $\begin{array}{l}0,0 \\
45\end{array}$ & & $\begin{array}{c}0,10 \\
4\end{array}$ & $\begin{array}{c}0,27 \\
7\end{array}$ \\
\hline \multicolumn{7}{|c|}{ Total Pengaruh (Rsquare) } & $\begin{array}{c}0,51 \\
3\end{array}$ \\
\hline
\end{tabular}

\subsection{Pembahasan}

Secara umum penelitian ini menunjukan hasil yang cukup memuaskan. Hasil analisis deskriptif menunjukan bahwa aplikasi e-PunTEN sebagai media informasi secara umum sudah baik. Tahap selanjutnya adalah pembahasan hasil analisis penelitian, yaitu sebagai berikut:

\section{A. Analisis Pengaruh Faktor Manusia Berpengaruh Signifikan Terhadap Niat Pengguna}

Dari hasil penelitian ini diketahui bahwa faktor manusia (Human factor) berpengaruh signifikan positif terhadap niat penggunaan (Behavioral intention) dengan tingkat hubungan $0,239^{2}=0,057$ atau $5,7 \%$. Dan setelah pengujian hipotesis dinyatakan signifikan sehingga dapat disimpulkan bahwa terdapat korelasi yang positif antara faktor manusia dan niat penggunaan. Hal ini menunjukan bahwa factor manusia menjadi variabel penting yang di pertimbangkan dalam niat penggunaan.

\section{B. Analisis Pengaruh Faktor Organisasi Berpengaruh Signifikan Terhadap Niat Pengguna \\ Dari hasil penelitian ini diketahui} bahwa faktor organisasi (Organization factor) berpengaruh signifikan positif terhadap niat penggunaan (Behavioral intention) dengan tingkat hubungan $0,172^{2}=0,029$ atau $2,9 \%$. maka pengujian hipotesis dinyatakan signifikan sehingga dapat disimpulkan bahwa terdapat korelasi yang positif antara faktor organisasi dan niat penggunaan. Hal ini menunjukan bahwa secara organisasi Dinas Kependudukan telah mendukung implementasi aplikasi e-PunTEN dengan menyediakan fasilitas berupa sarana dan prasarana serta fitur aplikasi yang lengkap.

\section{Analisis Pengaruh Faktor Teknologi Berpengaruh Signifikan Terhadap Niat Pengguna}

Dari hasil penelitian ini diketahui bahwa faktor teknologi (Technology factor) berpengaruh signifikan positif terhadap niat penggunaan (Behavioral intention). dengan tingkat hubungan $0,415^{2}=0,173$ atau $17,3 \%$. maka pengujian hipotesis dinyatakan signifikan sehingga dapat disimpulkan bahwa terdapat korelasi yang positif antara faktor teknologi dan niat penggunaan. Hal ini menunjukan bahwa faktor teknologi merupakan variabel yang penting untuk dipertimbangkan dalam niat penggunaan.

D. Analisis Faktor Manusia, Faktor Organisasi Dan Faktor Teknologi Berpengaruh Signifikan Terhadap Niat Pengguna.

Dari hasil penelitian ini diketahui bahwa Faktor manusia, faktor organisasi dan faktor Teknologi berpengaruh signifikan positif terhadap niat penggunaan (Behavioral intention) dengan tingkat hubungan $\mathrm{R}^{2}$ square= $0,515=51,5 \%$. Sisanya dipengaruhi oleh faktor lain sebesar $0,485=48,5 \%$ dan nilai $F$ tabel sebesar 2,70. Karena nilai $F$ hitung 33,966 lebih besar dari $F$ tabel 2,70 maka ditarik kesimpulan bahwa variabel bebas $X_{1}$, $X_{2}$, dan $X_{3}$ secara simultan berpengaruh terhadap variabel terikat. maka pengujian hipotesis dinyatakan signifikan sehingga dapat disimpulkan bahwa terdapat korelasi yang positif antara faktor manusia, faktor organisasi dan faktor teknologi.

$\begin{array}{llll}\text { E. Analisis Niat } & \text { Pengguna } \\ \text { Berpengaruh Signifikan } & \text { Terhadap } \\ \text { Kepuasan Pengguna } & \\ \text { Dari hasil penelitian ini diketahui }\end{array}$
bahwa niat penggunaan (Behavioral intention) berpengaruh signifikan positif terhadap kepuasan penggunaan (user satisfaction) dengan tingkat hubungan $0,722^{2}$ $=0,521$ atau $52,1 \%$. maka pengujian hipotesis dinyatakan signifikan sehingga dapat disimpulkan bahwa terdapat korelasi yang positif antara niat pengguna dan kepuasan penggunaan. Hal ini menunjukan niat pengguna merupakan variabel yang penting untuk dipertimbangkan dalam kepuasan penggunaan. 


\section{Kesimpulan}

Berdasarkan hasil pengujian atas model yang diajukan untuk meneliti kepuasan pengguna terhadap penggunaan palikasi e-PunTEN. Adapun kesimpulan yang dapat diambil pada penelitian dilakukan sebagai berikut :

1. faktor manusia (Human factor) berpengaruh signifikan positif terhadap niat penggunaan (Behavioral intention) dengan tingkat hubungan $5,7 \%$ menunjukan bahwa faktor manusia menjadi variabel penting yang di pertimbangkan dalam niat penggunaan.

2. faktor organisasi (Organization factor) berpengaruh signifikan positif terhadap niat penggunaan (Behavioral intention). dengan tingkat hubungan 2,9\% Menunjukan hasil signifikan sehingga dapat disimpulkan bahwa terdapat korelasi yang positif antara faktor organisasi dan niat penggunaan.

3. faktor teknologi (Technology factor) berpengaruh signifikan positif terhadap niat penggunaan (Behavioral intention). Dengan tingkat hubungan $17,3 \%$ dinyatakan signifikan sehingga dapat disimpulkan bahwa terdapat korelasi yang positif antara faktor teknologi dan niat penggunaan. Hal ini menunjukan bahwa faktor teknologi merupakan variabel yang penting untuk dipertimbangkan dalam niat penggunaan.

4. Faktor manusia (Human factor), faktor organisasi (Organization factor) dan faktor Teknologi (Technology factor) berpengaruh signifikan positif terhadap niat penggunaan (Use Behavioral). dengan tingkat hubungan $\mathrm{R}^{2}$ square $51,5 \%$. Sisanya dipengaruhi oleh faktor lain sebesar $48,5 \%$ dan nilai $F$ tabel sebesar 2,70. Karena nilai $F$ hitung 33,966. maka pengujian hipotesis dinyatakan signifikan sehingga dapat disimpulkan bahwa terdapat korelasi yang positif antara faktor manusia, faktor organisasi dan teknologi.

5. Niat penggunaan (Behavioral intention) berpengaruh signifikan positif terhadap kepuasan penggunaan (User satisfaction)) dengan tingkat hubungan 52,1\% dinyatakan signifikan sehingga dapat disimpulkan bahwa terdapat korelasi yang positif antara niat pengguna dan kepuasan penggunaan. $\mathrm{Hal}$ ini menunjukan niat pengguna merupakan variabel yang penting untuk dipertimbangkan dalam kepuasan penggunaan.

\section{Saran}

Sebagai hasil dari penelitian ini, maka terdapat beberapa saran dari peneliti, untuk dapat memaksimalkan penelitian dan penggunaan dari aplikasi e-PunTEN, yaitu sebagai berikut:

1. Untuk penelitian selanjutnya yang ingin mengembangkan penelitian ini dapat menambahkan variabel Moderating (Umur dan gender) serta variabel manfaat bersih.

2. Hasil penelitian ini dapat dikembangkan pada penelitian selanjutnya dengan penambahan jumlah sampel dan memodifikasi indikator.

3. Penelitian selanjutnya dapat melakukan penelitian yang sama, tetapi menggunkan pendekatan dan model yang evaluasi atau kerangka hipotesis yang berbeda.

\section{Referensi}

Agusta. (2013). Faktor-Faktor Yang Mempengaruhi Mobilitas Penduduk Ke Desa Kota Bangun Dua Kecamatan Kota Bangun Kabupaten Kutai Kartanegara: ISSN 2338-3615.

Istiqomah. (2017). Elektronik Pendaftaran Penduduk Tidak Permane. Diakses, 28 Okteober 2017: http://epunten.bandung.go.id/.

Jogiyanto. (2007). Model Kesuksesan Sistem Teknologi Informasi. Yogyakarta: Andi.

Martini \& Sudibia (2013). Keputusan Melakukan Mobilitas Penduduk Dan Dampaknya Terhadap Pendapatan Migran Di Kota Denpasar: ISSN: 23030178.

Misbahuddin, I. H. (2013). Analisis Data Penelitian dengan Statistika Edisi Ke-2. Jakarta: Bumi Aksara.

Mohamadali, N. A. (2010). A Novel Evaluation Model of User Acceptance of Software Technology In Healthcare Sector. International Conference on Health Informatics .

PP. (2009). Perubahan Atas Peraturan Pemerintah Nomor 27 Tahun 1994. Diakses 19 Oktober 2017: http://peraturan.go.id/pp/nomor-57tahun-2009.html. 
Yunita, R. (2017). Studi tentang Pelayanan Administrasi Kependudukan di Desa Bukit Makmur Kecamatan Kaliorang Kabupaten Kutai Timur. Jurnal Pemerintahan Integratif, 5(3), 378-389.

Ridwan. (2012). Dasar-dasar Statistika. Bandung: Alfabeta.

Venkatesh, V. (2003). User Acceptance of Information Technology: Toward a Unified view. MIS Quarterly (27:3),pp. , 425-278.

Yusof, M. M. (2006). Towards a Framework for Health Information Systems Evaluation. Proceedings of the 39th Hawaii International Conference on System Sciences . 